\title{
Sovereignty and European Integration: Deconstruction or Reconstruction of State Authority?
}

\author{
Scott N. Romaniuk ${ }^{1}$ \& Yannis A. Stivachtis ${ }^{2}$ \\ ${ }^{1}$ School of International Studies, University of Trento, Trento, Italy \\ ${ }^{2}$ Virginia Tech, Blacksburg, VA, United States \\ Correspondence: Yannis Stivachtis, Virginia Tech, 119 Major Williams Hall, Blacksbug, VA, 24061, United States. \\ E-mail: ystivachtis@vt.edu
}

Received: June 9, 2015 Accepted: July 9, $2015 \quad$ Online Published: July 24, 2015

doi:10.5539/res.v7n11p184 URL: http://dx.doi.org/10.5539/res.v7n11p184

\begin{abstract}
The purpose of this essay is twofold: first, to examine the nature of the European Union's system of governance; and second, to investigate the implications of the EU's institutional and decision-making arrangements for sovereignty. To this end, it engages a set of theories of European integration applied to a selection of developments of contemporary EU integration that have had different effects on EU Member States' sovereignty. The essay attempts to highlight the linkages between these theories to show how the current EU political organization of authority qualifies as "shared sovereignty" in practice. In doing so, it reviews the pillar theories of integration; explores the concepts of "integration" and "sovereignty"; and presents three levels of development that are used to frame wider and deeper integration and its effects on Member States resulting in the transfer and sharing of sovereignty.
\end{abstract}

Keywords: European Union, sovereignty, integration, constitution, federalism, liberal intergovernmentalism, neofunctionalism

\section{Introduction}

European integration and its impact on Member States constitute a major part of present-day research within the field of Political Science. While much of scholarly literatures portray the European Union (EU) as a successful reality predicated on unity, solidarity, and "closeness," debates about the EU, as a controversial polity, or political, social, and economic project have, over the past two decades and within the context of globalization, increasingly focused on the "state's claim to sovereignty" (Bellamy \& Castiglione, 1997). Integration advocates and critics remain at odds over the impact of institutions on state sovereignty despite claims through historical assessment that "the modern state has been treated as the superior form of political association" (Spruyt, 1994).

Although the European Council (hereafter "the Council") does not specifically reference the integration of the sovereign rights of states, the contention is strongly supported that states cede sovereign rights and empower the EU to act autonomously through integration, even issuing acts as a centralized polity with the "same force of law in individual states (Borchardt, 2010). Integration has therefore led to a deep friction, as it is the product of two competing principles. We argue that understanding the extent to which sovereignty rests with individual Member States or with the EU is related to the interaction between the Member States and the EU through three distinct categories of development: first, extra-state (non-governmental or non-state); second, state and sub-state; and third, supra-state.

The purpose of this article is twofold: first, to examine the nature of the European Union's system of governance; and second, to investigate the implications of the EU's institutional and decision-making arrangements for sovereignty. We engage a set of theories of European integration applied to a selection of developments of contemporary EU integration that have had different effects on EU Member States' sovereignty. We aim to highlight the linkages between these theories to show how the current EU political organization of authority qualifies as "shared sovereignty" in practice. In doing so, this article is structured into five sections. In the second section we briefly review the pillar theories of integration. We explore the concepts of "integration" and "sovereignty" in the third section. In section four we present three levels of development that we use to frame wider and deeper integration and it effect on Member States resulting in the transfer and sharing of sovereignty. 


\section{Theorizing European Integration}

When studying something as complex as the EU, we need conceptual tools to guide us. Theories simplify reality and allow us to see relationships between the things we wish to observe. Diez and Wiener (2004) discuss theory as "causal argument of universal, transhistorical validity and nomothetic quality," testable by exposing hypotheses to empirical falsification (Jackson, 2011; King, Keohane, \& Verba, 1994). Diez and Wiener (2004) argue that while empirical facts provide information that act as building blocks that could lead to impressions of certain phenomena, they can also be lacking in meaning, be misleading, or run the risk of being assumption-based; because of the complexity of the world of social science, mere observations and even "having more observations may assist us in this scientific process but it usually insufficient" (King, Keohane, \& Verba, 1994).

Diez and Wiener (2004) provide us with three core reasons for theoretical endeavor. First, without theories, we cannot fully explain or grasp the crux of EU integration processes and outcomes; second, because social science inquiry typically unearths further questions and proliferates concern about the nature other phenomena that "require a deeper understanding of the normative issues at stake"; and third, "pure' empirical knowledge of how institutions work is impossible." This is so because various concerns and assumptions will always seep into perceptions of EU operability and integration (Diez \& Wiener, 2004). With integration theory we are able to problematize ideas, expectations, and empirical matters. In short, "good theory often takes us beyond our current empirical knowledge" (Reus-Smit \& Snidal, 2008).

Over the past sixty years a number of theories have been formulated and proliferated by scholars in an attempt to explain different aspects of the European project, including its processes (i.e., understandings of the EU's formal institutions) in addition to "outcomes," "behavior," and "decision-making rationales" (Diez \& Wiener, 2004). These theories engage with questions of how and why regarding the emergence of the EU and its existence, function, and character to and within the present day. Much of their analytical value is the product of each "theoretical approach to European integration [being] informed by different understandings of the meaning and purpose of theorizing" (Diez \& Wiener, 2004).

In an attempt to comprehend the EU's system of governance and its implications for sovereignty, we will employ five main theoretical frameworks: Neofunctionalism, liberal intergovernmentalism, policy network theory, new institutionalism, and federalism. These theories are chosen for their theoretical strength, because they are able to provide the bases for robust empirical analysis, and because they are able to overlap one another in such a way as to allow for a fuller analysis of the empirical cases addressing aspects that others may not. Although some have been developed decades ago, they remain important today because they provide for a deep analysis and understanding of EU development while providing productive bases for developing meaningful hypotheses about future EU debates and the direction in which the EU and EU integration may or may not be heading. Each of these theories has its own assumptions, strengths, and weaknesses (Nelsen \& Stubb, 1998) and each offers different insights about different key features of the EU: How integration evolves; the way policies are made, the role of different actors is this process and, most importantly, where sovereignty lies.

The first two approaches-neofunctionalism and liberal intergovernmentalism-draw from the international relations theory and they are primarily concerned with explaining the European integration process. In other words, they seek to answer questions like: how and why European states have chosen to form European institutions, and who or what determines the shape and speed of the integration process?

\subsection{Neofunctionalism}

Neofunctionalism as a theory of regional integration is rooted in the 1950s and 1960s and was initially advocated with reference to the European Coal and Steel Community (ECSC) (Haas' main focus, 1958), the European Economic Community (EEC) (Lindberg's main focus, 1963), the European Atomic Energy Agency (EURATOM), and the Common Agricultural Policy (CAP), which fortified arguments put forward by neofunctionalists. Haas and others were concerned with explaining how a merger of economic activity in particular economic sectors, such as coal and steel, across borders could "spillover" and provoke wider economic integration in related areas, such as agriculture (Haas, 1958, 1964; Lindberg, 1963; Lindberg \& Scheingold, 1970). The idea of "spillover" is linked to actors at the supranational and subnational levels within the overall process of European integration, which according to neofunctionalism, is a self-supporting process, and that it would become reflexive, leading to the creation of a new polity. Haas (1975) later cited this proposition as one of the theory's flaws given that, "automaticity could not be assured and [Haas] queried the value and existence of spillover" (McGowan, 2007). Moreover, neofunctionalists asserted that this economic integration would produce political integration and the creation of common, integrated, supranational institutions to accelerate this process 
thereby transcending national borders, interests, and powers (Rosamond, 1999).

Haas (1958) and Lindberg (1963) laid the groundwork for subsequent cohorts to examine the European integration experience and apply the lessons to other sectors within the European community. It is, as Sandholtz and Stone Sweet (2012) assert, "a theory of market and political integration within a specific region constituted by those states that have taken a formal decision to integration." Questions about the cooperation in one sector (i.e., economic policymaking) and its potential impact on other areas (i.e., economic integration among European states), and eventually to others (i.e., political integration more generally) stems from the neofunctionalists' idea of "spillover" (Note 1) - a process leading to the creation of new political goals (Cini \& Perez-Solorzano, 2004) - as engrained in neofunctionalist pluralism.

More recent analysts, inspired by neofunctionalist thinking, work under the banner of "supranational governance" emphasizing the creation of supranational rules and society (Sandholtz \& Stone, 1998, 2012; Sandholtz, Stone, \& Flitgstein, 2001). In either case, neofunctionalism challenges the assumed primacy of the nation-state and the notion that international institutions are incapable of autonomous decisions and action. Neofunctionalism's unidirectional logic (integration could only go forward) was heavily criticized when European integration appeared to stagnate and even to reverse in the late 1960s and 1970s. Dissatisfaction with neofunctionalism led to the development of alternative theoretical models, especially "liberal intergovernmentalism."

\subsection{Liberal Intergovernmentalism}

Most closely associated with Andrew Moravcsik (1993, 1998), this theoretical approach builds on earlier writings of international relations scholars who rejected the notion that national governments might not be supreme, or that states would willingly relinquish sovereignty (Hoffman, 1995; Milward, 1992). Liberal intergovernmentalism's principle features are the product of its broader social science theory grounding, and its "application of 'rationalist institutionalism," cultivating scholarly analysis of interstate cooperation as regards IR and world politics (Moravcsik \& Schimmelfennig, 2009; Pollack, 2009). Hoffmann (1966) first wrote of this approach when he raised criticism against neofunctionalism and its adherents. During the 1990s, the European Community (EC) (Note 2) (which was in the course of becoming the EU at that point) experienced many changes in addition to both internal and peripheral issues. These included the break-up of Yugoslavia, the signing of the Treaty on the European Union (TEU), the solidification of the single market including its four freedoms, the accession of Austria, Finland, and Sweden, the Schengen Agreement having come into effect, the signing of the Treaty of Amsterdam, and the opening of negotiations for the membership of ten countries in Central and Eastern Europe (EU, 2015).

These were prolific changes that pushed Moravcsik to expand upon intergovernmentalism by adapting the theory to these and other major empirical developments witnessed across Europe. Although liberal intergovernmentalism, just as neofunctionalism, treats states as rational actors, each with their own sets of preferences, they had expanded their accounts of these primary actors to treat them as ones operating amid formations of domestic preference - a process of which economic interdependencies and sub-national actors were very much a part. Additions were made in the development of liberal intergovernmentalism. Preferences formulated within nation states contributed to processes of international negotiation, and the overall role of international institutions (IOs) was enhanced. Thus, the analytical purchase of liberal intergovernmentalism was considerably elevated so as to account for much of the wide and deep changes that constituted the impacting regional integration process. Pollack (2001) described this theoretical realignment by stating that, liberal intergovernmentalism "nests three complementary middle-range theories within larger rationalist framework: a liberal theory of national preference formation, an intergovernmental theory of bargaining, and a new theory of institutional choice stressing the importance of credible commitments."

Drawing on impressive historical evidence, liberal intergovernmentalists argue that major choices reflect the preferences of national governments rather than supranational organizations. Each state's preferences reflect the balance of their domestic economic interests. In this respect, the outcomes of EU negotiations are the result of intergovernmental bargaining (bargaining between sovereign national governments). Any subsequent delegation to supranational institutions is calculated, rational, and circumscribed. In other words, national governments are the dominant actors in shaping integration and they are in control. In the words of Moravcsik (1993), "governments first define a set of interests, then bargain among themselves to realize those interests."

\subsection{Policy Networks}

Another theoretical approach to the study of the EU's political system is the policy networks framework. Unlike neofunctionalism or liberal intergovernmentalism, this approach is not so much concerned about the policy bargains struck between national governments and their negotiations that lead to treaty reforms and that set the 
broad direction of European interaction. In contrast, network analysis is set to uncover the behind-the-scenes negotiation and exchange that can shape policies at a day-to-day level. According to Peterson and Bomberg (1999), a policy network is "a cluster of actors, each of which has an interest or stake in a given EU policy sector and the capacity to help determine policy success or failure." Policy networks at the EU level usually bring together institutional actors (European Commission, European Council, and European Parliament) and other stake holders such as representatives from private firms, public interest groups, technical or scientific experts, and most importantly, national officials. Networks lack hierarchy (there is no one actor in charge) and instead depend on resource exchange. That means participants need to bring them some valued resource with which to bargain: information, ideas, finances, constitutional-legal power, or political legitimacy. According to network analysts, bargaining and resource exchange among these actors-rather than intergovernmental bargaining - determine the shape of actual EU policies.

\subsection{New Institutionalism}

Analysts drawing on comparative politics approaches have challenged the primacy of the state in shaping European integration and the European Union. Among these approaches is new institutionalism, which emphasizes the importance of institutions in shaping and determining government preferences. In the EU context, new institutionalism demonstrates that not only the various EU's institutions (European Commission, European Council, European Parliament, or European Court of Justice) are not impartial arbiters in the policy-making process, but they actually are key players with their own agendas and priorities (Armstrong \& Bulmer, 1998; Bulmer, 1998). For new institutionalists, "institutions" refer not only to the executive (government), the legislative (parliament), and the judicial (courts) but also to values, norms, and informal conventions that govern social exchanges between actors. These values and norms affect or "frame" the way actors perceive the choices open to them. For example, rules, such as majority voting among government ministers, or information practices, like seeking consensus whenever possible, can shape the behavior of national government representatives in ways that governments cannot plan or control.

A second insight of new institutionalist analyses is the concept of "path dependency" - the notion that once a particular decision or path is chosen, "it is very difficult to get back on the rejected path" (Krasner, 1984). Path dependency means that it is hard to change a policy even when it outlives its usefulness. The "costs" in terms of time and resources already invested of agreeing on a policy in the first place are often considerable, and the idea of starting again on a long, time-consuming, and expensive process of agreeing on a new policy is resisted for that reason (Pierson, 1996; Peterson \& Bomberg, 1999).

\subsection{Federalism}

Federalist theory, it has been argued, forms an intricate part of a relationship with European integration in both concept and practice. Federalism figures significantly within the empirical context given that "it has transcended the familiar level of the nation state to the level of an unknown "ever closer union among the peoples of Europe"" (Burgess, 2004). Federalism, in essence, "is the application of federal principles to the process of European integration where the term "integration" refers to the sense of a coming together of previously separate or independent parts to form a new whole" (Burgess, 2004). The theory identifies an élite group as the core of an all-encompassing integration process. Consequently, the pluralist and civil society features of this core remain at odds with the role of national governments. Whereas liberal institutionalists look to three specific stages of integration, federalists identify an élite group or pressure group as the fundamental driver of integration. This view, however, is countered by the assertion that cooperation cannot exist in the absence of political leadership that actually favors the interests of the élite group. Nonetheless, the overarching federalist perspective that integration is a single "big bang" event rather than an ongoing process involving the negotiation of power sharing in this case reconciles the difference of opinion observed.

Federalism can be traced back to the Second World War, specifically 1941, at which point the famous Ventotene Manifesto (a Resistance declaration conceptualizing European integration) was drafted by Italian federalists "led by Altiero Spinelli and Ernesto Rossi (Burgess, 2004; Lipgens, 1982; Pinder, 1998). There are cases that point to Federalism as having a positive impact over recent years. Burgess (2009), for instance, argues that Federalism contributed to European integration through such projects as the creation of the European Defense Community (EDC) and federal objectives were the face of European integration vis-à-vis the "European Parliament's 1984 Resolution on the Draft Treaty Establishing a European Union (Koslowski, 2001; Burgess, 1989). Koslowski $(1999,2001)$ claimed that, "European federation was the explicit goal of several of the Community's founders and such federal aspirations as the Treaty of Rome." The assumptions that federalism makes about the process of integration provide a fruitful setting for the conceptualization of integration as unity, community, and identity 
(Note 3). As Burgess (2009) notes, federalism "has been constructed as a particular way of bringing together previously separate, autonomous, or independent territorial units to constitute a new form of union based upon principles that, broadly speaking, can be summarized in the dictum "unity in diversity."”

Federalism as a system of governance is based on the principle that the component units as well as the federation are usually geographically defined. As a result, federalism fulfils two major functions; first, a vertical separation of power by a division of responsibilities between two levels of government; and second, the integration of heterogeneous societies, while preserving their cultural and/or political autonomy (Borzel \& Risse, 2001). Both functions imply that the component units and the federation have autonomous decision powers, which they can exercise independently from each other. Thus, sovereignty is shared or divided.

One may observe that even without the legitimate monopoly of coercive force, the EU has acquired some fundamental federal qualities (Borzel \& Risse, 2001). For example, the EU possesses sovereignty rights in a wide variety of policy sectors reaching from exclusive jurisdiction in the area of Economic and Monetary Union to far-reaching regulatory competences in sectors such as transport, energy, environment, consumer protection, health and social security. In most policy areas, Community law superior to national law giving, among other things, citizens the right to litigate against their own states for violating their rights conferred to them by Community law.

It may be argued (Cloots, Baere, \& Sottiaux, 2012) that the EU is transforming itself into a political community within a defined territory and with its own citizens, who are granted some fundamental rights by the European Treaties and the jurisdiction of the European Court of Justice. The European Community was initially conceptualized as a primarily functionally defined organization of economic integration without fixed territorial boundaries and no direct relationship between its institutions and the European citizens. With the Treaties of Maasrticht and Amsterdam, however, the Single Market has been embedded in a political union with emerging external boundaries and a proper citizenship.

As a political community with comprehensive regulatory powers and a proper mechanism of territorially defined exclusion and inclusion (Union citizenship), the EU shares most features of what the literature defines as a federation (Burgess 2000). For example, the EU's system of governance which has two levels of government, each existing under its own right while the European Treaties allocate jurisdiction and resources to these two main levels of government. There are also provisions for shared government in areas where the jurisdiction of the EU and the Member States overlap whilst Community law enjoys supremacy over national law. Moreover, European legislation is increasingly made by majority decision obliging individual Member States against their will. At the same time, the composition and procedures of the European institutions are based not solely on principles of majoritarian representation, but guarantee the representation of minority views. Yet, the European Court of Justice serves as an umpire to adjudicate conflicts between the European institutions and the Member States. Finally, since 1979, the EU has a directly elected parliament (Borzel \& Risse, 2001).

If the EU is viewed as a federal system where formal and material sovereignty is divided and shared, federalism offers different alternatives to organize the distribution of power vertically (between the European Union and the Member States), and horizontally, between the executive and legislature. In principle, we can distinguish two federal models (Schutze, 2013), which differ according to the distribution of competences between the two levels (shared versus divided), the representation of the states at the federal level (strong versus weak), and the fiscal system (joint versus separate). Cooperative or intra-state federalism is based on a functional division of labor between the different levels of government. While the federation makes the laws, the states are responsible for implementing them. The vast majority of competences are concurrent or shared. On the other hand, dual or inter-state federalism emphasizes the institutional autonomy of the different levels of government, aiming at a clear vertical separation of power (checks and balances). Each level should have an autonomous sphere of responsibilities. Competences are allocated according to policy sectors rather than policy functions. For each sector, one of the two levels of government has both legislative and executive powers. As a consequence, the entire machinery of government tends to be duplicated because each level should manage its own affairs autonomously.

On the other hand, the EU lacks two significant features of a federation: first, the Member States remain the "masters" of the treaties in the sense that they have the exclusive power to amend or change the constitutive treaties of the European Union: and second, the EU lacks fiscal federalism. It is on these very points that Moravcsik attacks the view that current developments in the EU herald the advent of a European federal state. According to Moravcsik (2001), the EU lacks and is likely to continue to lack the fundamental competences that would make it federal. To make this point, Moravcsik emphasizes what the EU does not do and is unlikely to 
take on in the foreseeable future, spelling out how the "EU plays almost no role in most of the issue - areas about which European voters care most, such as taxation, social welfare provision, defense, high foreign policy, policing, education, cultural policy, human rights, and small business policy" (Moravcsik, 2001).

\section{Integration and Sovereignty}

This section is concerned with defining and problematizing both the terms "integration" and "sovereignty." Problematizing these terms is necessary not only to formulate a multidimensional understanding of them before they are applied but also to understand that they can, depending on their ontological treatment, be distinguished from themselves. The necessity of doing so is the result of the polemic changes that have been observed in the relationship between states and statehood, and (European) integration, particularly since the 1980s (Note 4) and even more so since the 1990s through the EU's “'widening' and 'deepening,' with its the EU's agenda dominated by the policies of enlargement of Economic and Monetary Union," which has "provoked a public backlash in some member state of the EU, as evidenced in the ratification debates on the Maastricht and Amsterdam treaties" (Beetham \& Lord, 1998). More generally, the question is embedded within a debate about the metamorphosis of the modern state system (i.e., 1500 onward) habitually studied within the field of Political Science and International Relations (IR) ( Ruggie, 1993). General notions contend that states have yielded much ground to postmodern configurations of political, social, economic, and legal space. In the case of the EU, this matter is about states relinquishing their sovereign powers as traditionally rooted in the Westphalian system of statehood and state sovereignty (otherwise referred to as Westphalian sovereignty, Note 5). Friction between these concepts is rooted in interpretations of political rule and the ways in which "rule comprises legitimate dominion over a spatial extension (Ruggie, 1993). This section, however, does not seek to present a philosophical exchange about models of legitimacy by virtue of dominant or "rightful" jurisdiction, recognition, or affirmation. Rather, the intention is to present an overview of different interpretations of these terms so as to suggest that they lend themselves to different theoretical and empirical assumptions.

Much of the existing literature on the EU explores the idea of a European "identity," "Europeanization," and "EUrification." These terms are inherently linked not only to a changing Europe, specifically the changing nature of statehood within Europe including state sovereignty and authority, but also to increasing levels of integration and possibly restrained sovereignty for Member States. Earlier works by Haas (1958) and Deutsch $(1953,1957)$ refer to the concept of identity and present a concrete foundation for discussion. Whereas Haas (1958) pointed distinctly to a "shift in loyalties" to a "new political center" in the process that involves "political actors in several distinct national settings, Deutsch (1957) accentuates the "shared" element as part of the concept that he defines as, "a matter of mutual sympathy and loyalties; of 'we-feeling,' trust and mutual consideration; of partial identification in terms of self-images and interests; of mutually successful predictions of behavior, and of cooperative action in accordance with it." Easton (1975) referred to a "sense of social community" as something that "emerges between people regardless emphasis added of the type of political regime they live in" (Scheuer \& Schmitt, 2009). Because this area of inquiry runs so deep and is so expansive, we can also draw on terminology and postulations related to such concepts as "democracy," "citizenship" (Habermas \& Derrida, 2005; Habermas, 2006; Castiglione, 2009), "Europeanization" (Note 6) (Delanty, 2005) and "community" (Olsen, 2002; Börzel \& Risse, 2000, Cowles, Caporaso, \& Risse, 2001), "communitarianism" (Calhoun, 2003; Manners, 2011) and "supranational community" (Schmidt, 2004, 2006; Cini, 2007; Conant, 2002; Kostakopoulou, 2001).

While it would be nearly impossible to capture all of the competing and complementary perspectives and terms about EU integration, it is beneficial to present a few and delve deeper into how they refer to and connect with this complex process. Delanty (2005) characterizes Europeanization as a "social reality" challenging two overarching perspectives of integration: (1) "Europeanization is a question of the transformation of the nation-state" and (2) "Europeanization is leading to the integration of European societies." However, in both cases we find that states are in one way or another undergoing a transformation process, which leads to positive change, negative change, or a settlement somewhere in the middle. If the former two suggest too stark a dichotomy, we might also refer to the process regarding the two as one that leads to the "deconstruction" of state authority or to "re-constitution" of the state into much broader, adaptable, and variegated political community organized in a particular way. Pentland (Burgess, 2004) defined integration as a "process whereby a group of people, organized initially in two or more independent nation states, come to constitute a political whole which can in some sense be described as a community." The EC, as the manifestation of integration processes, represents a "successful intergovernmental regime designed to manage economic interdependence through negotiated policy coordination" (Moravscik, 1993). Emphasis is placed on interdependence but we should also draw attention to the management aspect of this product of integration. Rejecting the notion of "many Europes," 
Schimmelfennig, Leuffen, and Rittberger (2011) sees the EU as a "single organizational and member state core and a territorial outreach that varies by function." Although in one way this view would lend credibility that the EU enjoys or "resembles a state's authority pattern" (Schimmelfennig et al., 2011), there exists a great deal of variation regarding "centralization." Thus, states are able to engage differentially in sectors of EU enlargement (Note 7). Haas and Haas (2002) reference to integration back in the 1950s shares strong linkages with what we see theoretically and empirically as the EU today - the creation of "dual or multiple identities" as community for individuals, non-state actors, state and sub-state organizations, and supra-state authority, which proliferates disagreements about the idea of sovereignty, orders of power, and subordination.

Sovereignty is a "crucial concept in International Relations theory" that is repeatedly subjected to "redefinition and reinterpretation as situations change" and over a period of many years has assumed a broad spectrum of "denotations and connotations" (Keohane, 2002). Indeed, there are many different kinds of sovereignty (Risse, 2010; Krasner, 2004). Because the "changing meanings of sovereignty enable it to be used as a conceptual lens, through which attitudes and policy preference are refracted," it has become an important feature of EU integration and debates about the changing nature of state authority. Stemming from the rigid interpretation of sovereignty articulated by Jean Bodin as far back as 1577 , who stated that "sovereignty cannot be divided (Keohane, 2002)," Keohane (2002) presented the idea of "external sovereignty" as a form of self-determination or authority that is "subject to no other state and has full and exclusive powers within its jurisdiction without prejudice to the limits set by applicable law." Here, the caveat is the interpretation of "applicable law." Whereas Hoffman eludes to fixed powers within a particular political space and Krasner's (Keohane, 2002; Krasner, 1999) "Westphalian sovereignty" enunciates the prevention of the "delegation of powers over the state to an external authority," Keohane (2002) reasons that EU Member States have departed considerably from these classical meanings. "Sovereignty," argues Keohane (2002), "is pooled similar to the idea of "shared", in the sense that, in many areas, states' legal authority over internal and external affairs is transferred to the Community as a whole, authorizing action through procedures not involving state vetoes."

Lake (2003) refers to sovereignty as a "type of authority relationship" about voluntary compliance but one that nonetheless includes command and obedience. There are three characteristics of authority worth mentioning: (1) Power is a foundation of authority but is not reliant on coercion, and it entails volunteerism, (2) authority is justifiable by means of "divine right, tradition, and popular support," and (3) authority is measurable by the distance between command and preference, and voluntary compliance (Lake, 2003). Rather than sovereignty being treated as a constraining norm, we might treat it as a regulative idea such as "democracy or equality," which are problematic in and of themselves simply because "regulative ideas by definition cannot be flawless, and they comprise of different components that need to be evenly balanced" (Zürn, 2002). It is precisely because of these myriad subjectivities of sovereignty that we can see the reorientation of EU Member States' authority as a political kaleidoscope.

\section{Developments and State Transformation}

\subsection{Extra-State-Blurring Boundaries}

The role of extra-state actors, or international organizations (IOs) and non-state actors (NSAs), and their "participation" in positive governance within a state's sovereignty territory has garnered much attention for over a decade. During that time, external actors, norms, and "functional equivalents" of state governance have built-up a spritely debate about governance in general and specifically new modes of governance (NMG). Within the extra-state area delegated bodies and NMG allows for the representation of social actors at different levels of interest (i.e., EU level to sub-state and non-state) that do not register through existing conventional channels of governance (Bellamy \& Castiglione, 2011). According to Tömmel (2006), "it was the decline of the intervention state and the increasing responsibility of non-state actors in public decision- and policy-making, which gave rise to the concept of governance as a more cooperative mode of steering society." A constructive response to claims that the EU infringes upon the sovereignty of Member States is the idea that the EU, taken as a supranational polity, is also challenged by its own limited formal competencies in addition to its own shortage of sovereignty. Moravcsik (2002) discussed the EU "superstate" endowed with extensive sovereign powers, "defending" against critics of EU legitimacy by accentuating the often-overlooked constraints, including its substantive and administrative constraints, decentralized political of implementation, procedural constraints including checks and balances, legal constraints and competences, two faces of accountability [direct and indirect], semi-autonomous judges, and deliberation and legitimacy). By advocating for a perspective beyond stand-alone ideal-type democracies and not just acknowledging that, "constraints cannot be assumed away," it is clear how "EU decision-making procedures ... are very much in line with the general practice of most modern democracies" (Moravscik, 2002). 
With the Open Method of Coordination (OMC) (Note 8) (also referred to as "a third way"; Hamburg, 2008), we see the inclusion of so-called "soft-law" or "soft forms of governance" (Tömmel, 2006) that brings states into closer cooperation with one another but without imposing upon them "directives, regulations, or decisions" (EU, 2015). Procedures take place within the framework of the Lisbon Agenda (2000-10) with state planning and policy formulation (pertaining to a wide array of issues, like employment, social protection, social inclusion, education, youth, and training) being sent to the Commission (EU, 2015). NMG distinguishes between "government" and "governance," (Note 9) expressing diversification of sovereignty horizontally and vertically, reaching difference levels of governance within the EU itself. This process "is triggered," according to Tömmel (2006), "by the very nature of the EU-system and the perception of this system as representing the current shift in public steering from state-centered activity to a more cooperative approach, including, not only different levels of public authority from local to European, but also non-state actors on all these levels."

The OMC and its ability to promote institutional spillover is championed by neofunctionalists who, as noted previously, claim that it is the critical driving element of integration with deepening taking place in one sector to produce further economic integration in that same sector and beyond. The supranationalist character of neofunctionalism places "egoistic and rational societal actors involved in transnational activities at the heart of European integration whenever they have the opportunity to transmit their demand for supranational governance to powerful pro-integrative supranational organizations" (Hamburg, 2008). Activity across states cultivates European standards, coordination, solutions-based instruments, the culmination of which is the desire for supranational governance.

In the context of education and training, EU-level abilities to bring about positive change might be weak or ineffective. From the supranational level, however, when the Maastricht Treaty entered into force in 1992, EU Member States were given the responsibility of education. Later developments led to the integration, upon Council decision, of quality assurance and mobility (Hamburg, 2008) or as Gorniztka (2005) describes, three strategic goals: (1) Enhance quality and effectiveness of education and training, (2) increase access of these systems, and (3) make education and training open to the world. Management structures were created at the EU-level to implement the plan with working groups established over subsequent years (Gorniztka, 2005). In areas of "content of teaching," "teacher training," and "language learning," as part of the coordination process, the OMC constitutes a success story. While EU-level institutions focused on particular aspects of the process, others are met vis-à-vis political objectives mutually identified, a systematic method, and the accessibility of the "larger political order of the EU" (Gornitzka, 2005; Hamburg, 2008).

This effective relationship, the so-called "community method," (Note 10) was particularly attractive for its decentralized approach - a departure from the federal polity aspiration of genuine federalists keen for a "United States of Europe" through "the abolition of Europe's independent nation-states" (Morgen, 2005) —and for its "naming and shaming" (Note 11) approach pressuring but not stepping so far as to coerce Member States to meet standards and avoid lagging behind the group (Culture Action Europe, 2015). Kröger (2009) sees this as "subtle forms of influence on the basis of new information, and ongoing communication and exchange between involved actors." Although far from being a neutral instrument, within the OMC Member States are not required to "produce national action programs (NAPs), peer reviews are not allowed, and neither the Commission nor Council are permitted to make recommendations in fields other than those covered by Articles 149 and 150 of the TEC Treaty of the European Community" (Hamburg, 2008).

There are a number of valid theoretical and empirical takeaway points from this brief engagement. The OMC does not mean a transfer of power from member states to the EU as the Commission, for example, only retains "certain traditional elements of governance: notably a hierarchical division of competences, binding decisions, and the more-or-less uniform and strict implementation of rules through the use of sanctions for non-compliers" (Bellamy \& Castiglione, 2011). We do not see the application of restrictive or binding rules as a result of majority decision-making, even in spite of the Commission's control over several important aspects of the OMC process, and the $\mathrm{OMC}$ does not seek to centralize authority or formulate and implement policy. Moreover, the OMC does not empower any particular body such as the European Court of Justice (ECJ) to level sanctions against Member States that violate Community law.

The OMC operates between the ideals of LI, the principles of federalism, fulfills expectations of neofunctionalists, and even forges pathways of shared authority between holders of power within layers of EU government. While empowering the EU indirectly so as to establish agreed upon standards and practices, the OMC tempers the Commission's powers by reducing its direct influence on Member States' authority. These avenues for achieving integration and meeting expectations, established partially by the super-state bodies, could also be interpreted as roads to supranational governance or "process of developing supranational characteristics 
yet of a different kind than the law-based conferral of state sovereignty to a supranational level, as it caters to a deliberative supranationalism or deliberative network governance" (Gornitzka, 2005). Proponents of the middle-range theory of State Centrism might see the OMC as a process of the collective will of states utilizing a panoply of supranational institutions resulting in the two-level game of national politicians operating on the domestic and EU level. Even from this point of view, the powers of the Commission, the ECJ, and the European Parliament (hereafter "the Parliament") are restrained. If the OMC ensures state authority over core areas such as employment, social policy, education, and allows for the EU interested to be served, the OMC could be viewed as a share victory.

\subsection{State and Sub-State-Europe of the Regions?}

When the Committee of the Regions (CoR) was created in 1994, after the Maastricht Treaty came into effect, it was considered a great leap forward for the EU project and a significant aspect facilitating "deeper" and "wider" integration. Over two decades the initiative has earned support from proponents and opponents. For neofunctionalism, LI, and federalism, the CoR is the product of efforts by actors at various levels of governance. From this interaction stem positive and negative developments followed by steps to further "institutionalization of the "third level," with more utopian scenarios going as far as speculating that the CoR would eventually be transformed into a new legislative changed, alongside the European Parliament and the Council" (Christiansen \& Lintner, 2005).

Intrinsic to the $\mathrm{CoR}$ is the concept and practice of diversity. They become manifest in the structure and operations of the CoR by intersecting ideas, opinions, and efforts of "regional, local, and intermediate levels of government" (Christiansen \& Lintner, 2005) - the embodiment of the principle of self-government. Diversity usually comes at a price and the CoR internal political set-up is no exception. CoR members form sub-groups with unique interests. There is notable friction between representatives of regions that are administrative and legislative. Thus, representatives have natural advantages and suffer from disadvantages according to categorical lines. The result can be divisions among Member States of the EU.

However, through such divisions emerge prospects for communication and cooperation, which speak to neofunctionalism's main attributes, namely a range of actors, motives (community creators), and the functional and political directions of "spillover." The CoR allows for shifting loyalties, and for expectations and political activities to move toward a significant political core. Rather than claiming that through the CoR one sees the state ceasing to be wholly sovereign, the voluntary mingling and merging results in state sovereignty being elevated. With the lessening of objective features of sovereignty, the state and its political groups gain new capabilities to make decisions within the politicization of the EU. Divisions, however, breed subdivisions; this is precisely what occurs within the CoR, which prevents an expected "consensualism that was initially expected from it (Christiansen \& Lintner, 2005).

The CoR attracts the attention and serve the needs of actors above and below it. Acting as a transmission belt of ideas, opinions, and interests, the CoR lends itself to the interests and therefore needs of the Commission by accommodating reviews and evaluations of EU policy, reports, and formal proposals. The "CoR Draft Opinion-Towards a Circular Economy: Review of EU Waste Legislation," as a response to the Commission's recycling and municipal waste target schemes exemplifies this working relationship whereby the CoR's "Environment, Climate Change, and Energy Commission" (ENVE) support the EU-level initiative but call for explanations of how the EU's proposals would actually work (EU/CoR, 2015a; EU/CoR, 2014a). Contributions have also been made to the EU's enlargement Strategy and the unique functions that local and regional actors play in the EU's European Neighbourhood Policy (ENP), particularly as they relate to the EU's post-"big bang" accessions of 2004 and 2007 by addressing enlargement in the context of the EU's neighbours to the east and to the south (EU/CoR, 2015b; EU/CoR, 2014b). The ideas of collaborative regionalism and competition among EU Member States were also palpable during the formation of the European Foundation Statute (EFS) between 2012 and 2014 (European Foundation Center (EFC), 2015). The Commission's presentation of the plan to "facilitate the cross-border activities of public benefit purpose foundations and make it easier for them to support public benefit causes across the EU" was backed by the Parliament but consensus between the 28 Member States' representatives did not occur (EFC, 2015).

The Statute, which is "citizen-focused" and aims at "more public goods to people and communities most in need" (EFC, 2015) was a disappointment to the regions of Europe despite being the outcome of a process that would satisfy neofunctioalists' expectations for an ideal setting for political actors in specific national settings to shift their interests, and proponents of LI accept that preference-formation is able to take place in addition to intergovernmental bargaining and institutional lock-in of bargains (Note 12). The EFS process, on one hand, ran 
the risk of stepping on particular regional interests had their not been a mobilization of political actors and interest groups that could influence the direction of EU reform and policy. Deciding on the EU agenda in such a way, on the other hand, captures what federalists would have liked to avoid in the interest of catering to a process of decision-making "not geared to the interests of citizens across Europe" (EFC, 2015).

In the context of sovereignty and EU enlargement, the CoR is an important body that gives an impression of how intergovernmentalism, supranationalism, and federalism co-exist, the mingling of which encapsulates the idea of collaborative regionalism, competitive regionalism, and complementary regionalism (Weatherill \& Bernitz, 2005). Because EU Member States have decided to enter into union, it is clear that decision made in one area of the EU will have an effect in other areas. Seeing how integration could move forward without a body like the CoR is difficult given that between $70 \%$ and $80 \%$ of "EU policies require implementation by regional and local authorities (Christiansen \& Lintner, 2005). Thus, both the EU and its Member States should have a genuine interest in sharing sovereignty as they directly benefit. Further, making one's voice heard through the CoR is a positive way to balance the laudable voices of both nationalists and federalists, who consistently dominate the debates about Europe's political trajectories. European citizens benefit from know that direction lies somewhere in the middle. While the Commission includes in its reports all of the CoR's opinions, whether mandatory or voluntary, none of the CoR's opinions are binding. This maintains a reasonable degree of power between various levels. As (Christiansen \& Lintner, 2005) state, "the most recent instance of Treaty change was novel in the sense that the Convention method invited other actors beyond national governments, and civil society more generally, to participate in the debate about the "future of Europe."'

\subsection{Supra-State-Lost Powers? National Sovereignty and EU Law}

Once a relatively faint piece of the EU project, the ECJ has become a predominant aspect with considerable control over the EU and its Member States. Anti-federalists laudably claim that ideals of national self-determination or sovereignty/state authority have withered away due to its authority to interpret and constitutionalize EU treaties, penalizing Member States for failure to meet the criteria established in Community law, and exercise its power of direct effect, usurping the authority of national courts in cases regarding citizens of nations in which those same courts exist and operate. Contrary to the view that national sovereignty is fading amid the powers of the ECJ, national sovereignty can be considered strengthening precisely through the same legal framework that opponents of supra-state authority would claim weakens it. Article 4(2) of the Treaty of the European Union (TEU), is explicit about the EU respecting the "equality of the Member States before the Treaties as well as their national identities, inherent in their fundamental structures, political and constitutional, inclusive of regional and local self-government" (Consolidated Version of the Treaty of the European Union, 2012)

An important distinction exists between primary rulings and proceeding, and how they "affect" Member State sovereignty. With proceedings, states are accountable to a higher authority to which they previously agree to become accountable whereas primary rulings are matters are take place almost entirely within national courts. However, concern is raised over their impact on sovereignty. For example, the ECJ has "not infrequently crossed the dividing line between interpreting and applying the law and actually creating it" (Aston, 2004). "Extending the remit of the law" (Aston, 2004), the ECJ fosters integration via judicial activism. Numerous cases are the expression of this concept, namely the case of Tanja \& Bundesrepublik in 2000. This case concerned Kreil's application for a volunteer position with the Bundeswehr involving duties in weapons maintenance. Her application was rejected on the grounds that women were not allowed to serve in military positions under German national law (Germany's Soldatengesetz Law on Soldiers and Soldatenlaufbahnverordnung Regulations on Soldiers' Careers) (Tanja \& Bundesrepublik, 2000). Bringing action against the Administrative Court of Germany (Verwaltungsgericht), the claims was made that Kreil was discriminated against on the bases of sex and in a manner that contradicted European Community law (Tanja \& Bundesrepublik, 2000). The case is notable for its direct effects. Community law produced new responsibilities for Germany and bestowed a new set of rights for women. The ruling compromised the sovereignty of Germany in definitional terms, though by assuming precedence over national law it provided opportunities for rights to be extended and for the ECJ to expand its power even after having become a supreme court.

Lesbian, gay, bisexual, (queer), and transgender (LGBQT) rights in the context of the EU and Member States shows a different side of the ECJ's political power. Article 6 of the TEU states that the EU is required to respect "fundamental rights, as guaranteed by the European Convention for the Protection of Human Rights and Fundamental Freedoms and as they result from the constitutional traditions common to Member States, shall constitute general principles of the Union's law" (TEU Art. 6). Combating discrimination based on sexual orientation is also included in the TFEU (Art. 10). Article 19 of the TFEU explicitly states that, "the Council, 
acting unanimously in accordance with a special legislative procedure and after obtaining the consent of the Parliament, may take appropriate action to combat discrimination based on sex," (also included in Art. 13 of the Treaty of the European Community [TEC]) among other issues. Thus, the Commission is able to "submit draft Directives," which the Council of Ministers then deliberate and decide upon "by unanimity after obtaining the consent of the European Parliament" (Waele \& Vleuten, 2011). Several years after the Kreil case, the Employment Equality Framework Directive (Directive 2000/78/EC) came into force (EU, 2000), calling on Member States to invoke Article 19 of the TFEU in their efforts to mitigate discrimination.

Although one might expect the powers of the ECJ and Community law to substantiate that fundamental principles of the Community are supreme, the outcome was much different. The European Agency for Fundamental Rights (FRA, 2010; EC, 2008) reported on homophobia, transphobia, and extensive discrimination and stereotyping toward LGBT peoples showing " $51 \%$ of EU respondents perceived sexual orientation discrimination as a widespread." But to proponents of fundamental rights upheld within the EU, the conflicting views concerning LGBT issues prevents the EU by way of the EJC and Community law from encroaching on the sovereignty of Member States by "reviewing national legislation in light of the TEU's Article 6," according to de Waele \& van der Vleuten (2011), reasoning further that, "after all, it only provides for protection of fundamental freedoms as they "result from the constitutional traditions common to the Member States." LGBT rights in the EU provide a window for observing the limits of the EJC and the supra-state's authority over Member States. What might otherwise be perceived as an issue at the very core of EU values to ensure that no person is "left outside the protective shield of the prohibition to discriminate on the basis of sex" (Lisa Jacqueline Grant v. South-West Trains Ltd., 1998), the ECJ must also ensure that rulings even on special cases "reflect the legal traditions of a majority of the Member States" (Waele \& Vleuten, 2011).

\section{Conclusion}

In this article, we explored three theories of European integration from which we examined the extent that sovereignty of the EU Member States is ceded to an EU supranational polity. In the second section, we briefly engaged with three pillar theories of European integration. In the third section, we problematized the terms "integration" and "sovereignty." Our aim was to problematize aspects of these areas that might either be taken for granted or that, through the theories presented previously, might produce assumptions that would ultimately require clarification. At the same time, these terms could also be further conceptualized so as to lend themselves readily to both the theories discussed and to empirical developments. In the fourth section, we presented divergent channels of development, outlining the linkages between each theoretical position and these developments in the context of European integration.

EU Member State sovereignty, rather than judged in terms of relative gain where the strengthening of the powers of the EU come at the expense of state power or authority on the national level, can be better understood through political interactions that take place through categories of development. On one hand, the EU has shown a considerable level of acceptance of the interests and desires of states as well as sub-state actors. On the other hand, the at the supra-state level, the EU has significantly influenced Member States through the ECJ in legal and constitutional matters, but has also provided Member States with opportunities to express their normative positions in order to block attempts by the EU at harmonization through its regulatory approaches. The developments also show that unconditional support to any single theory of European integration cannot be made and that accounts of sovereignty by way of singular theoretical accounts prove rather reductive and unidimensional.

\section{References}

Approaches to the State. (1984). Comparative Politics, 16(2), 223-246. http://dx.doi.org/10.2307/421608

Armstrong, K., \& Bulmer, S. (1998). The Governance of the Single European Market. Manchester: Manchester University Press.

Beck, U., \& Grande, E. (2010). Empire Europe: Statehood and Political Authority in the Process of Regional Integration. In T. Diez, \& W. Antje (Eds.), European Integration Theory. Oxford, UK: Oxford University Press.

Beetham, D., \& Lord, C. (1998). Legitimacy and the EU. New York, NY: Addison Wesley Longman.

Bellamy, R., \& Castiglione, D. (1997). Building the Union: The Nature of Sovereignty in the Political Architecture of Europe. Law and Philosophy, 16, 421-445. http://dx.doi.org/10.1007/978-94-017-1152-4_4

Börzel, T. A., \& Risse, T. (2000). When Europe Hits Home: Europeanization and Domestic Change. European Integration Online Papers (EIoP), 4. 
Bulmer, S. (1998). New Institutionalism and the Governance of the Single European Market. Journal of European Public Policy, 5(3), 365-386. http://dx.doi.org/10.1080/135017698343875

Burgess, M. (1989). Federal and European Union. Abingdon, UK: Routledge.

Burgess, M. (2000). Federalism and European Union: The Building of Europe, 1950-2000. London: Routledge. http://dx.doi.org/10.4324/9780203465325

Castiglione, D. (2009). Political Identity in a Community of Strangers. In J. T. Checkel, \& P. J. Katzenstein (Eds.), European Identity (pp. 28-51). Cambridge, UK: Cambridge University Press. http://dx.doi.org/10.1017/CBO9780511806247.003

Christiansen, T., \& Lintner, P. (2005). The Committee of the Regions after 10 Years: Lessons from the Past and Challenges for the Future. Eipascope Bulletin, 1, 7-13.

Cini, M. (2007). From Integration to Identity: Administrative Ethics and Reform in the European Commission. Manchester, UK: Manchester University Press.

Cini. M., \& Perez-Solorzano, B. N. (2004). European Union Politics. Oxford, UK: Oxford University Press.

Cloots, E., Baere, G., \& Sottiaux, S. (Eds). (2012). Federalism in the European Union. London: Hart Publishing.

Commission for Citizenship Governance, Institutional and External Affairs-Enlargement Strategy and Main Challenges 2013-2014. (2014b). Draft Opinion at 22 ${ }^{\text {nd }}$ Commission Meeting, Brussels, Belgium. Retrieved from http://toad.cor.europa.eu/ViewDoc.aspx?doc=cdr\%5ccivex-v\%5cdossiers $\% 5$ ccivex-v-046\% 5cEN\%5cCOR-2013-06834-00-00-PA-EDI_EN.doc\&docid=2969002

Conant, L. (2002). Justice Contained: Law and Politics in the European Union. Ithaca, NY: Cornell University Press

CoR Draft Opinion-Towards a Circular Economy: Review of EU Waste Legislation. (2014a). Working Document at $25^{\text {th }}$ Commission Meeting, Brussels, Belgium. Retrieved from http://www.toad.cor.europa.eu/ViewDoc.aspx?doc $=$ cdr $\% 5$ cenve-v $\% 5$ cdossiers $\% 5$ cenve-v- $048 \% 5 \mathrm{cEN} \% 5 \mathrm{cC}$ OR-2014-04083-00-00-DT-TRA_EN.doc

Cowles, M. G., Caporaso, J., \& Risse, T. (2001). Transforming Europe: Europeanization and Domestic Change (Cornell Studies in Political Economy). Ithaca, NY: Cornell University Press.

Culture Action Europe. (2015). The Open Method of Coordination. Retrieved from $\mathrm{http} / / /$ ec.europa.eu/culture/policy/strategic-framework/european-coop_en.htm

Delanty, G. (2005). The Idea of Cosmopolitan Europe: On the Cultural Significance of Europeanization. International Review of Sociology, 15(3), 405-421. http://dx.doi.org/10.1080/03906700500272434

Democracy by Delegation? Who Represents Whom and How in European Governance. (2011). Government and Opposition, 46(1), 101-125.

Democracy in Europe: The EU and National Polities. (2006). Oxford, UK: Oxford University Press.

Deutsch, K. (1953). Nationalism and Social Communication: An Inquiry into the Foundations of Nationality. Cambridge, MA: Massachusetts Institute of Technology (MIT) Press.

Easton, D. A. (1975). A Re-Assessment of the Concept of Political Support. British Journal of Political Science, 5, 435-457. http://dx.doi.org/10.1017/S0007123400008309

ECJ, Lisa Jacqueline Grant v. South-West Trains Ltd., Case C249/96, 1998.

ECJ, Tanja Kreil v. Bundesrepublik Deutschland, Case C-285/98, 2000.

EFC. (2015). 20/11/2014-Foundations Denied Freedom of Movement Across Europe. Retrieved from http://www.efc.be/news_events/Pages/Foundations-denied-freedom-of-movement-across-Europe.aspx

EU. (Dec. 13, 2007). Treaty on the Functioning of the European Union (Consolidated Version), 2008/C 115/01.

EU Enlargement Strategy and Neighbourhood Policy to Dominate Debate at Next CIVEX Meeting. (2015b). Retrieved from http://cor.europa.eu/en/news/Pages/enlargement-neighbourhood-policy-civex.aspx

EU. (2015a). Europe without Frontiers. Retrieved from http://europa.eu/about-eu/eu-history/1990-1999/index_en.htm

EU/CoR. (2015a). We Need an Ambitious Review of the EU Waste Targets-And We Need it Soon. Retrieved from http://cor.europa.eu/en/news/Pages/EU-Waste.aspx 
European Commission. (2008). Discrimination in the EU: Perceptions, Experiences, and Attitudes, Special Eurobarometer 296/Wave 69.1, Brussels, Belgium. Retrieved from http://ec.europa.eu/public_opinion/archives/ebs/ebs_296_en.pdf

European Integration and Supranational Governance. (1998). Oxford, UK: Oxford University Press.

Federalism. (2009). In T. Diez, \& A. Wiener (Eds.), European Integration Theory (pp. 25-44). Oxford, UK: Oxford University Press.

FRA. (2010). Homophobia, Transphobia, and Discrimination on Grounds of Sexual Orientation and Gender Identity in the EU Member States. Vienna, Austria. Retrieved from http://fra.europa.eu/sites/default/files/fra_uploads/1659-FRA-homophobia-synthesis-report-2011_EN.pdf

Gornitzka, A. (2005). Coordinating Policies for a Europe of Knowledge: Emerging Practices of the "Open Method of Coordination" in Education and Research (working Paper No. 16). University of Oslo, Norway: $\begin{array}{lllll}\text { Center for } & \text { European } & \text { Studies. }\end{array}$ http://www.eucenter.wisc.edu/OMC/papers/other/gornitzka.pdf

Haas, E. B. (1958). The Uniting of Europe: Political, Social, and Economic Forces, 1950-1957. Stanford: CA: Stanford University Press.

Haas, P. M., \& Haas, E. B. (2002). Pragmatic Constructivism and the Study of International Relations. Millennium, 31(3), 573-601. http://dx.doi.org/10.1177/03058298020310031001

Habermas, J. (2006). The Divided West. Cambridge, UK: Polity.

Habermas, J., \& Derrida, J. (2003). February 15, or What Bings European Together: A Plea for a Common Foreign Policy, Beginning in the Core of Europe. Constellations, 10(3), 291-297. http://dx.doi.org/10.1111/1467-8675.00333

Hamburg, M. (2008). The Open Method of Coordination and European Integration: The Example of European Education Policy. Berlin, Germany: Free University of Berlin. Retrieved from http://www.polsoz.fu-berlin.de/polwiss/forschung/international/europa/arbeitspapiere/2008-8_Humburg_Op enMethodofCoordination.pdf

Hoffman, S. (1987). Janus and Minerva: Essays in the Theory and Practice of International Politics. Boulder, CO: Westview.

In Defence of the 'Democratic Deficit': Reassessing Legitimacy in the European Union. (2002). Journal of Common Market Studies, 40(4), 603-624. http://dx.doi.org/10.1111/1468-5965.00390

Jackson, P. T. (2011). The Conduct of Inquiry in International Relations: Philosophy of Science and its Implications for the Study of World Politics. Abingdon, UK: Routledge.

Keeler, J. T. S. (2005). Mapping EU Studies: The Evolution from Boutique to Boom Field 1960-2001. Journal of Common Market Studies, 43, 551-582. http://dx.doi.org/10.1111/j.0021-9886.2005.00569.x

Keohane, R. O. (2002). Ironies of Sovereignty: The European Union and the United States. Journal of Common Market Studies, 40(4), 743-765. http://dx.doi.org/10.1111/1468-5965.00396

King, G., Keohane, R. D., \& Verba, S. (1994). Designing Social Inquiry: Scientific inference in Qualitative Research. Princeton, NJ: Princeton University Press.

Kooiman, J. (2003). Governing as Governance. London, UK: SAGE.

Koslowski, R. (1999). A Constructivist Approach to Understanding the European Union as a Federal Polity. Journal of European Public Policy, 6(4), 561-578. http://dx.doi.org/10.1080/135017699343478

Kostakopoulou, D. (2001). Citizenship, Identity, and Immigration in the European Union: Between Past and Future. Manchester, UK: Manchester University Press.

Krasner, S. D. (1999). Sovereignty: Organized Hypocrisy. Princeton, NJ: Princeton University Press. http://dx.doi.org/10.1515/9781400823260

Kröger, S. (2009). The Open Method of Coordination: Underconceptualization, Overdetermination, De-Politicization, and Beyond. European Integration Online Papers, 1(13), 1-22. Retrieved from http://eiop.or.at/eiop/pdf/2009-005.pdf

Lake, D. A. (2003). The New Sovereignty in International Relations. International Studies Review, 5, 303-323. http://dx.doi.org/10.1046/j.1079-1760.2003.00503001.x 
Lindberg, L. (1963). The Political Dynamics of European Economic Integration. Stanford, CA: Princeton University Press.

Lipgens, W. (Ed.). (1982). History of European Integration (Vol. 1, pp. 1945-1947). Oxford, UK: Clarendon.

Loughlin, J. (2005). The Regional Question, Subsidiarity, and the Future of Europe. In S. Weatherill, \& U. Bernitz (Eds.), The Role of Regions and Sub-National Actors in Europe (pp. 157-169). Oxford, UK: Hart.

McGowan, L. (2007). Theorizing European Integration: Revisiting Neo-Functionalism and Testing its Suitability for Explaining the Development of EC Competition Policy. European Integration Online Papers, 11. Retrieved from http://eiop.or.at/eiop/index.php/eiop/article/view/2007_003a

Moravcsik, A. (1993). Preferences and Power in the European Community: A Liberal Intergovernmentalist $\begin{array}{lllll}\text { Approach. Journal of Common Market Studies, 31(4), 473-524. } & \text {. }\end{array}$ http://dx.doi.org/10.1111/j.1468-5965.1993.tb00477.x

Moravcsik, A. (2001). Federalism in the European Union: Rhetoric and Reality. In N. Kalypso, \& H. Robert (Eds.), The Federal Vision: Legitimacy and Levels of Governance in the US and the EU. Oxford: Oxford University Press. http://dx.doi.org/10.1093/0199245002.003.0007

Moravcsik, A., \& Schimmelfennig, F. (2009). Liberal Intergovernmentalism. In A. Wiener, \& T. Diez (Eds.), European Integration Theory. Oxford, UK: Oxford University Press.

Morgen, G. (2005). The Idea of a European Superstate: Public Justification and European Integration. Princeton, NJ: Princeton University Press.

Neofunctionalism and Supranational Governance. (2012). In E. Jones, A. Menon, \& S. Weatherill (Eds.), The Oxford Handbook of the European Union. http://dx.doi.org/10.1093/oxfordhb/9780199546282.001.0001

Olsen, J. (2002). .The Many Faces of Europeanisation. Journal of Common Market Studies, 40(5), 921-952. http://dx.doi.org/10.1111/1468-5965.00403

Open Method of Coordination. (2015b). Retrieved from $\mathrm{http} / /$ europa.eu/legislation_summaries/glossary/open_method_coordination_en.htm

Peterson, J., \& Bomberg, E. (1999). Decision-making in the European Union. New York: Palgrave.

Pierson, P. (1996). The Path to European Integration: A Historical Institutionalist Analysis. Comparative Political Studies, 29(2), 123-163. http://dx.doi.org/10.1177/0010414096029002001

Pinder, J. (1992). European Community: The Building of a Union. Oxford, UK: Oxford University Press.

Political Community and the North Atlantic Area. (1957). Princeton, NJ: Princeton University Press.

Pollack, M. A. (2001). International Relations Theory and European Integration. Journal of Common Market Studies, 39(2), 245-264. http://dx.doi.org/10.1111/1468-5965.00286

Reus-Smit, C., \& Snidal, D. (2008). Between Utopia and Reality: The Practical Discourse of International Relations. In C. Reus-Smit, \& D. snidal (Eds.), The Oxford Handbook of International Relations. Oxford, UK: Oxford University Press. http://dx.doi.org/10.1093/oxfordhb/9780199219322.003.0001

Risse, T. (2010). Governance Under Limited Sovereignty. American Political Science Association (APSA) 2010 Annual Meeting Paper, Free University of Berlin (FUB)—Center on Translatlantic Foreign and Security Policy Studies. Retrieved from http://papers.ssrn.com/sol3/papers.cfm?abstract_id=1642081

Rosamond, B. (1999). Theories of European Integration. New York: Palgrave.

Ruggie, J. (1993). Territoriality and Beyond: Problematizing Modernity in International Relations. International Organization, 47(1), 139-174. http://dx.doi.org/10.1017/S0020818300004732

Sandholtz, W., Stone, S. A., \& Fligstein, N. (Eds.) (2001). The Institutionalization of Europe. Oxford, UK: Oxford University Press.

Scheuer, A., \& Schmitt, H. (2009). Dynamics of European Political Identity. Journal of European Integration, 31(5), 551-568. http://dx.doi.org/10.1080/07036330903145856

Schimmelfennig, F., Leuffen, D., \& Rittberger, B. (2011). Ever Looser Union? Towards a Theory of Differentiated Integration in the EU. Paper Presentation at European Union Studies Association (EUSA) Conference, Boston MA, United States. Retrieved from http://www.euce.org/eusa/2011/papers/9g_schimmelfennig.pdf

Schmidt, V. (2004). The European Union: Democratic Legitimacy in a Regional State? Journal of Common 
Market Studies, 42(4), 975-999. http://dx.doi.org/10.1111/j.0021-9886.2004.00537.x

Schutze, R. (2013). From Dual to Cooperative Federalism. Oxford: oxford University Press.

Sharing Sovereignty: New Institutions for Collapsed and Failed States. (2004). International Security, 29(2), 85-120. http://dx.doi.org/10.1162/0162288042879940

The European Constitutional Compromise and the Neofunctionalist Legacy. (2005). Journal of European Public Policy, 12(2), 349-386. http://dx.doi.org/10.1080/13501760500044215

The New Institutionalism and European Integration. (2009). In A. Wiener, \& T. Diez (Eds.), European Integration Theory. Oxford, UK: Oxford University Press.

The Uniting of Europe: Political, Social, and Economic Forces, 1950-7. (1958). London, UK: Stevens.

Tömmel, I. (2006). Modes of Governance in the EU. Paper Presented for the Conference Governance and Policymaking in the EU, Osnabrueck, Austria. Retrieved from http://web.uvic.ca/jmtrg/Papers_files/Modes\%20of\%20Governance\%20in\%20the\%20EU.book\%20chapter, 23.10.06doc_1.pdf

Treaty of the European Union (Consolidated Version), Treaty of Maastricht. (Dec. 24, 2002). Official Journal of the European Communities, C-325/5.

Understanding European Union as a Federal Polity. (2001). In K. E. Jørgensen, \& A. Wiener (Eds.), The Social Construction of Europe. London, UK: SAGE.

Waele, H., \& Vleuten, A. (2011). Judicial Activism in the European Court of Justice-The Case of LGBT Rights. Michigan State Journal of International Law, 19(3), 639-666.

Who is Afraid of a European Federation? How to Constitutionalize a Multi-level Governance System. (2001). In C. Joergers, Y. Meny, \& J. H. H. Weiler (Eds.), In What of Constitution for What Kind of Polity? (pp. 45-59). Florence: European University Institute.

Zürn, M. (2002). From Independence to Globalization. In W. Carlsnaes, T. Risse-Kappen, T. Risse, \& Simmons, B. A. (Eds.), Handbook of International Relations. London, UK: SAGE. http://dx.doi.org/10.4135/9781848608290.n12

\section{Notes}

Note 1. The "spillover effect", according to Lindberg (1963), is "a situation in which a given action, related to a specific goal, creates a situation in which the original goal can be assured only by taking further actions, which in turn create a further condition and a need for more action and so forth." The term "spillover" was initially used to describe only a few dynamics of neofunctionalism with "functional," "political," and "cultivated" spillover having become a part of later generations of neofunctional lexicon (Sandholtz \& Stone, 2012).

Note 2. The term "European Community/Communities" here refer to the three aforementioned international organizations under the direction of the same institutions and that eventually (via the Maastricht Treaty) formed the EU in 1993.

Note 3. Although related to the ambiguous vision of an "ever closer union," in accordance with the 1983 Solemn Declaration on the European Union, no formal policy leading to a federalist state is in place.

Note 4. Keeler (2005) refers to the evolution, transformation, and proliferation of EU studies during this period as a movement from "a boutique field in decline to a boom field" entailing "not simply a vast increase in scholarly output, but also a dramatic diffusion of EU expertise in both North America and Europe" in the field of Comparative Politics and IR, and other subfields.

Note 5. We recognize Westphalian sovereignty as a product of the period in which it was formulated and is reflective of the sovereignty conceived of by such classicists as Thomas Hobbes (Leviathan, 1651), Jean Bodin (i.e., sovereignty as undivided and absolute), and Emmerich de Vattel but treat it as a strong basis relevant to the role of states today.

Note 6. Delanty (2005) writes extensively on Europeanization by employing the term "cosmopolitanism" and "global Europe" to differentiate a unique and communal European identity from a "national Europe." The former terms are both used to talk about an EU identity as a "form of post-national self-understanding that expresses itself within, as much as beyond, national identities."

Note 7. Divergent ontological positions on EU institutional shifts or reorientations are captured in its 
surrounding discourse (i.e., "enlargement," "expansion," "integration," "widening," and "imperialism").

Note 8. The OMC was classified a European mode of governance in March 2000 during the Lisbon Summit and was fueled by members states' fear of growing Commission influence in politically-sensitive areas (Hamburg, 2008).

Note 9. For conceptualizations of "government" and "governance" (Kooiman, 2003).

Note 10. Laffan and Shaw (2005) use the term "community method lite.)

Note 11. Kröger (2009) has also referred to "lessons-drawing," "policy transfer," "diffusion," and "benchmarking" in the OMC concept of "learning" and its overall effectiveness.

Note 12. The three-step process (Moravcsik, 1998) is an extension of Moravcsik's (1993) two-step process of preference formation and bargaining (Moravcsik, 2005).

\section{Copyrights}

Copyright for this article is retained by the author(s), with first publication rights granted to the journal.

This is an open-access article distributed under the terms and conditions of the Creative Commons Attribution license (http://creativecommons.org/licenses/by/3.0/). 